\title{
НАСЛІДКИ ВПЛИВУ ТРИВАЛОГО ПАСИВНОГО БАТЬКІВСЬКОГО ТЮТЮНОПАЛІННЯ НА СТАН РАНОВОГО ПРОЦЕСУ, НАДНИРКОВІ ЗАЛОЗИ ТА РІВЕНЬ КОРТИКОСТЕРОНУ У НАЩАДКІВ-САМИЦЬ ЩУРІВ
}

\author{
Ткаченко В. М. ${ }^{1}$, Комісова Т. С. ${ }^{2}$, Галій А. I. ${ }^{2}$
}

${ }^{1}$ Харківська спеціалізована школа I-III ступенів № 134, м. Харків, Украӥна;

${ }^{2}$ Харківський національний педагогічний університет іл. Г. С. Сковороди,

л. Харків, Украӥна

annetka1999@ukr.net

Одним із негативних i розповсюджених у сучасному житті впливів на дитину є тютюнопаління батьків [1]. Патологічні зміни, що виникають у плода під впливом нікотинової інтоксикації, мають прояв у період неонатального розвитку і в ранньому постнатальному онтогенезі, що доведено в експериментальних та клінічних дослідженнях [1-7]. Слід підкреслити, що саме хронічна дія тютюнового диму є більш розповсюдженою, ніж гострий його вплив [5].

Актуальним залишається питання про вплив тютюнопаління на органи ендокринної системи, бо вони є найбільш чутливими до дії хімічних чинників. Особливе місце серед ендокринних залоз відводиться наднирковим залозам, як одній з основних ланок адаптації, що регулюють компенсаторно-пристосувальні процеси. Надниркові залози є важливою складовою гіпоталамогіпофізарно-адреналової системи. Вони характеризуються великою лабільністю і здатні до швидкої функціонально-морфологічної перебудови. За станом надниркових залоз, як ефректорної ланки стресорної відповіді, з певною часткою ймовірності можна судити про активність структурно-фрункціональних систем [8]. Напрацьована достатня кількість експериментальних даних, що на гістологічному та ультратонкому рівнях описують структурні зміни тканин надниркових залоз, які виникали в результаті

\footnotetext{
* Дослідження виконано відповідно до планів кафедри анатомії та фізіології людини природничого факультету Харківського національного педагогічного університету імені Г. С. Сковороди в рамках наукової теми «Вплив факторів середовища на організм в онтогенезі» (№ держреєстрації 0187.0228336) і в рамках цільової науково-дослідної роботи Центральної науково-дослідної лабораторії Харківського національного медичного університету «Порушення в морфофункціональному стані інегративних систем плоду за умов материнського неблагополуччя» (№ держреестрації 0102U001871).

Установою, що фінансуе дослідження, е МОЗ України.

Автори гарантують повну відповідальність за все, що опубліковано в статті.

Автори гарантують відсутність конфлікту інтересів і власної фінансової зацікавленості при виконанні роботи та написанні статті.

Рукопис надійшов до редакції 12.03.2021.
} 
термічної травми шкіри, гіпотермії, нітратної інтоксикації та при введенні біологічно активних речовин [9].

На сьогодні лише в окремих роботах висвітлено питання негативного впливу тютюнопаління батьків на надниркові залози їх нащадків [6]. Недостатньо вивченим залишаеться питання реактивності дитячого організму на запальні процеси, обтяжені батьківським тютюнопалінням. Незважаючи на значні досягнення у науковому пізнанні фізіологічних механізмів негативного впливу компонентів тютюнового диму на фізичний і психічний стан активних та пасивних курців, у сучасній науковій літературі майже відсутні кон- кретні дані про наслідки впливу тривалого пасивного тютюнопаління батьків на стан механічної рани і надниркові залози їхніх нащадків. Крім того, ряд аспектів залишаються до кінця не з'ясованими, зокрема відсутня інформація щодо впливу різних доз нікотину та смол на фізіологічні процеси під час загоення рани. Отже, дана проблема $є$ актуальною і потребуе комплексного експериментального дослідження.

Виходячи $з$ актуальності, метою дослідження постало дослідити вміст кортикостерону та стан ранового процесу в нащадків-самиць першого покоління на тлі тривалого пасивного батьківського тютюнопаління.

\section{МАТЕРІАЛИ І МЕТОДИ}

Експериментальне дослідження проведене на 137 щурах лінії Вістар (40 самиць, 15 самців, 82 нащадків жіночої статі).

Усі маніпуляції з тваринами виконувалися відповідно до вимог положень «Європейської конвенції про захист хребетних тварин, які використовуються для експериментальних та інших наукових цілей» (Страсбург, 1986) і норм біомедичної етики, відповідно до закону України «Про захист тварин від жорстокого поводження» [10].

Щури-батьки (самці і самиці) підлягали тютюновій інтоксикації у спеціально сконструйованій камері об'ємом 27 л [11]. Тютюновий дим від $1 / 2$ цигарки нагнітався до камери, у якій одночасно перебувало 5 щурів одніеї статі впродовж 15 хв. $\mathrm{У}$ експерименті використовувалися цигарки з фільтром (з вмістом 0,6 мг нікотину та 12 мг смоли) та цигарки без фільтру (з вмістом 0,8 мг нікотину та 15 мг смоли). Тварини контрольної групи перебували у камері 15 хв і не обкурювалися. Підтвердженням хронічної інтоксикації щурів-батьків тютюновим димом $е$ статистично значуще збільшення в їх сироватці крові концентрації головного метаболіту нікотину — тіоцианіду К (котиніну), що показано в наших попередніх дослідженнях [12].

Щури обкурювалися до парування (30 обкурювань) та під час вагітності (21 обкурювання). Слід зауважити, що самиці не обкурювалися під час лактації.
У нащадків жіночої статі, отриманих від тварин обкурюваних тютюновим димом, та від тварин, які не обкурювалися, для моделювання больового стресу у 2 місячному віці робили механічні рани (довжина -10 мм, ширина -3 мм) на зовнішній поверхні стегна правої задньої кінцівки. Такі методики нанесення ран в експериментальних дослідженнях застосовують при вивченні імуноендокринної відповіді [13-15]. Вони є виправданими оскільки діти часто травмуються та отримують подряпини та порізи шкіри.

Стан ранового процесу та морфофункціональний стан надниркових залоз у нащадків жіночої статі досліджували на 24 годину і на 48 годину після нанесення механічної рани.

У залежності від доз нікотину в цигарках, парування обкурюваних самиць або самців та строку дослідження ранового процесу їх нащадків-щурят, сформовані наступні групи: К24 (n = 5), К48 (n = 5) нащадки-самиці контрольної групи (щурибатьки не підлягали тютюновій інтоксикаціï); ПБ24 ( $\mathrm{n}=5)$, ПБ48 ( $=6)$ - нащадки-самиці, народжені від пар, де тютюновій інтоксикації цигарками з фільтром підлягав лише самець; ПМБ24 (n = 7), ПМБ48 $(\mathrm{n}=10)-$ нащадки-самиці, народжені від пар, де тютюновій інтоксикації цигарками 3 фільтром підлягали самець та самиця; ВБ24 (n = 10), ВБ48 ( $=9)$ - нащад- 
ки-самиці, народжені від пар, де тютюновій інтоксикації цигарками без фільтру підлягав лише самець; ВМБ24 (n = 10), ВМБ48 $(\mathrm{n}=15)$ - нащадки-самиці, отримані від пар, де тютюновій інтоксикації цигарками без фільтру підлягали самець та самиця. Щурят виводили з експерименту через 24 години та 48 годин після нанесення механічної рани.

Після евтаназії у нащадків-самиць були взяті надниркові залози та частини шкіри з механічною раною для вивчення їх морфологічних особливостей. Залози та шкіру фіксували в 10\%-му нейтральному формаліні, збезводнювали в спиртах висхідної концентрації та заливали в парафрінові блоки. Зрізи товщиною 5-6 мкм забарвлювали гематоксиліном-еозином. Світлову мікроскопію проводили на мікроскопі Zeiss (Німеччина). Мордометрію надниркових залоз та частин шкіри щурів здійснювали за допомогою мікроскопа «Біолам» (Російська Федерація) при збільшеннях ×100, ×400. Мікрофротографрування проводилося на мікроскопі «Olympus» (Японія). У полі зору мікроскопа при збільшеннях ×100, ×400 аналізували видалені ділянки шкіри. Ширину пучкової зони надниркових залоз виміряно за допомогою мікроскопа ЛОМО з окулярмікрометром AM2-9.

Рівень кортикостерону у плазмі крові двомісячних щурят контрольної, експериментальних груп та референтні значення (Р.З.) визначені імуноферментним методом 3 використанням наборів «ELISA Corticosterone DRG»(Germany). Редерентні значення порівнювали 3 показниками контрольних груп тварин, яким були нанесені механічні рани. Імовірність відмінностей оцінювали за допомогою t-критерію Стьюдента. Критерієм статистичної вірогідності отриманих результатів була прийнята величина $\mathrm{p} \leq 0,05$. Отримані у ході дослідження результати були оброблені за допомогою спеціалізованих статистичних пакетів SPSS 10.0 з функціональними додатками.

\section{РЕЗУЛЬТАТИ ТА ЇХ ОБГОВОРЕННЯ}

Наслідки тривалого батьківського тютюнопаління у піддослідних нащадківсамиць у відповідь на больовий стрес (нанесення механічної рани) проявилися в залежності від концентрації нікотину в цигарках та від обкурювання одного з батьків (групи ПБ24, ПБ48, ВБ24, ВБ48), або обох батьків (групи ПМБ24, ПМБ48, ВМБ24, ВМБ48).

Виявлено, що рівень кортикостерону у плазмі крові щурят групи К24 статистично значимо збільшувався на $22 \%$, у групі К 48 - на $17 \%$ у порівнянні з референтними значеннями (рис. 1).

Разом з тим, відмічено зменшення рівня кортикостерону у щурят групи К 48 у порівнянні до щурят групи К24. Це є адекватною відповіддю на зменшення рівня больового стресу (механічна рана) і підтверджено в інших дослідженнях [16].

Відомо, що підвищений рівень кортикостерону зменшуе запальну реакцію, що встановлено ще за часів Г. Селье. У попередніх наших дослідженнях ми спостерігали нормальне протікання запального процесу в щурят контрольних груп на тлі динаміки рівня кортикостерону на 24 годину і 48 годину [12, 17, 18].

$\mathrm{y}$ нащадків-самиць щурів, де обкурювався тільки батько (ПБ24, ПБ48), відмічено зниження рівня кортикостерону у плазмі крові на $16 \%(\leq 0,05)$ та на $18 \%(\leq 0,05)$ у порівнянні з групами К24 і К48 (див. рис. 1). Зменшення рівня кортикостерону у нащадків-самиць щурів груп ПБ24, ПБ48 відбувалося, як встановлено нами раніше, на тлі зменшення ширини пучкової зони (де й відбувається синтез корикостерону) у порівнянні з групами К24 і К48: у щурят групи ПБ24-на $26 \%$, у щурят групи ПБ 48 - на $32 \%$ [18].

Означені морфофрункціональні зміни надниркових залоз викликали порушення перебігу ранового процесу у цих щурят. Так, нами показано, що у щурят груп ПБ24, ПБ48 біля рани наявний більш виразний набряк м'язового шару та васкуляризація грануляційної тканини, наявні ділянки гнійного запалення [17]. 


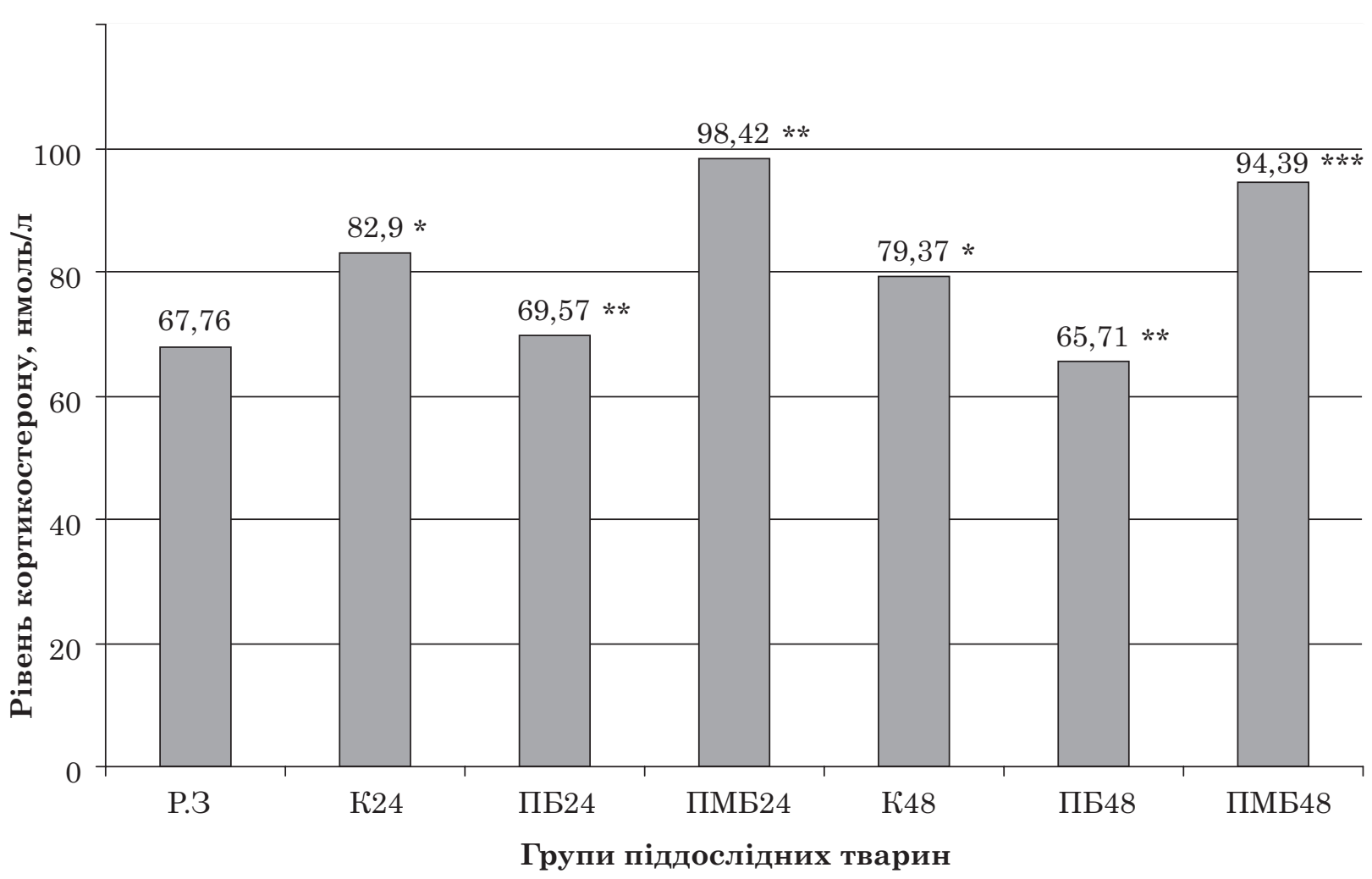

Рис. 1. Рівень кортикостерону в плазмі нащадків,

батьки яких обкурювалися цигарками з фільтром,

через 24 год та 48 год після нанесення механічної рани;

* вірогідність різниці порівняно з референтними значеннями (Р.3.), при $\mathrm{p} \leq 0,05$

** вірогідність різниці порівняно з групою $К 24$, при $\mathrm{p} \leq 0,05$,

*** вірогідність різниці порівняно з групою $К 48$, при $\mathrm{p} \leq 0,05$.

У групах нащадків, де обкурювалися самець і самиця (ПМБ24, ПМБ48), відмічали зворотні зміни морфофункціонального стану надниркових залоз, а саме: значне збільшення рівня кортикостерону у групі ПМБ24 на $19 \%(\leq 0,05)$, у групі ПМБ $48-$ на $18 \%$ $(\leq 0,05)$ щодо аналогічних показників у щурів контрольної групи (див. рис. 1). Збільшення рівня кортикостерону у крові щурят відбулося на тлі збільшення ширини пучкової зони на $15 \%(\leq 0,01)$ у групі ПМБ24 та на $16 \%(\leq 0,01)$ у групі ПМБ48 у порівнянні з групами К24 і К48 [18]. Такі зміни у морфофункціональному стані надниркових залоз у нащадків груп ПМБ24 і ПМБ48 призвели до порушення протікання ранового процесу. Він характеризувався формуванням некротизованої тканини, більш інтенсивним гістолізом, невеликим прогресуванням гнійного ексудату. Зафіксовано руйнування колагену та ділянки прогресування за типом флегмони [12]. У дослідженнях Полікарпової А. В. (2011) також виявлено, що значне збільшення концентрації адренокортикотропного гормону і кортикостерону супроводжуеться порушенням репаративного процесу і незагоєнням дефекту при радіаційному опіку.

Pentkowski N. S. та співав. (2011) зазначають, що нікотин збільшуе рівень кортикостерону у крові експериментальних тварин.

$\mathrm{y}$ нащадків самиць, батьки-щури яких обкурювалися цигарками з більшим вмістом нікотину та смол (групи ВМБ24, ВМБ48), як наведено у наших дослідженнях, не спостерігали збільшення пучкової зони у порівнянні з групами К24 і К48 [12]. При цьому концентрація кортикостерону в цих групах статистично значимо зменшувалася порівняно з групами К24, К48: у групі ВМБ24 - на $9 \%(\leq 0,05)$, у групі ВМБ 48 - на $15 \%(\leq 0,05)$ (рис. 2$)$.

У групах ВБ24, ВБ48 у плазмі крові щурят відмічали й тенденцію до зниження рівня кортикостерону (див. рис. 2). 


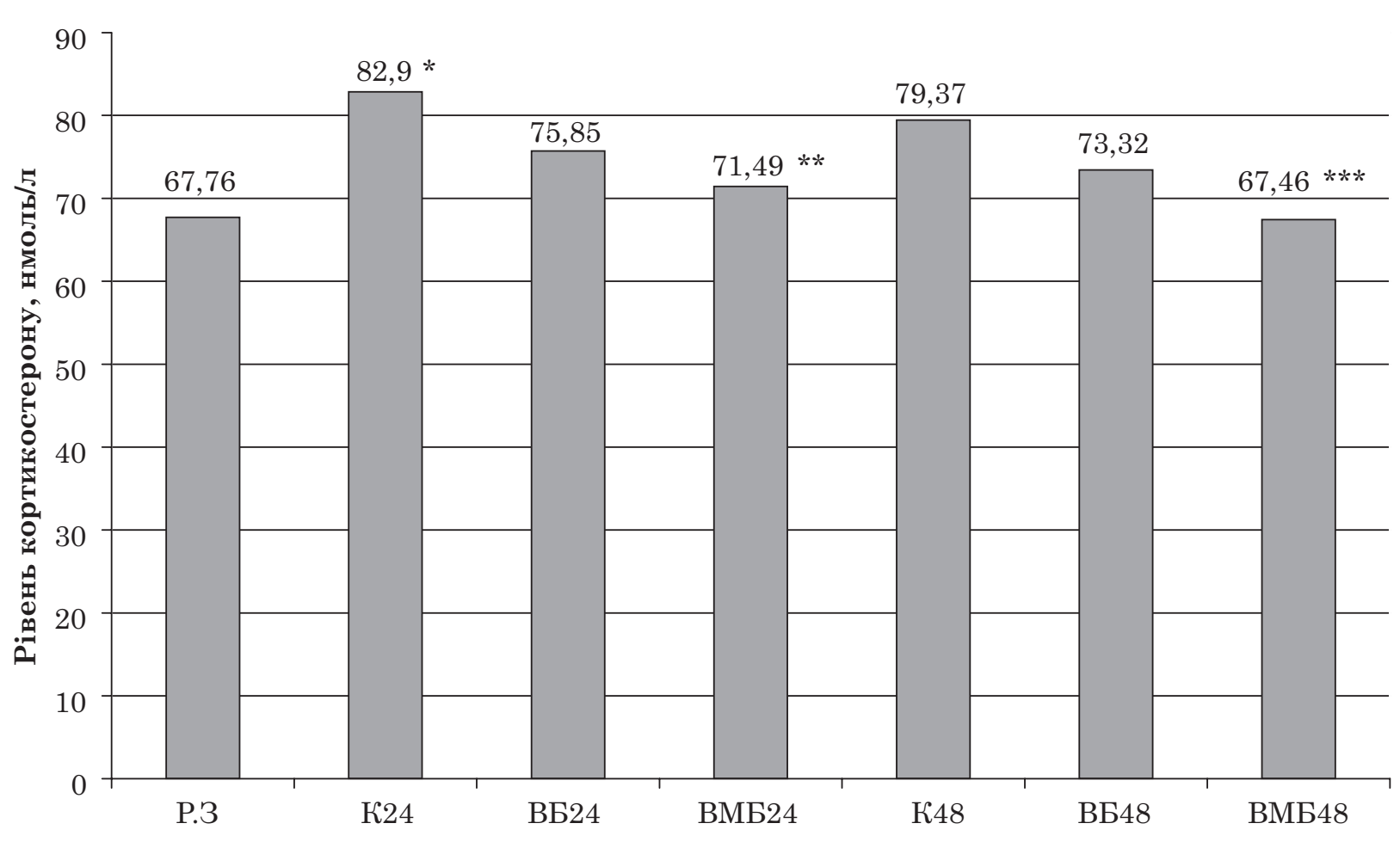

Групи піддослідних тварин

Рис. 2. Рівень кортикостерону у плазмі нащадків,

батьки яких обкурювалися цигарками без фільтру, через 24 год та 48 год після нанесення механічної рани;

* вірогідність різниці порівняно з референтними значеннями (Р.3.), при $\mathrm{p} \leq 0,05$,

** вірогідність різниці порівняно з групою К 24 , при $\mathrm{p} \leq 0,05$,

*** вірогідність різниці порівняно з групою $\mathrm{K} 48$, при $\mathrm{p} \leq 0,05$.

На тлі зниження рівня кортикостерону в цих групах протікання ранового процесу відбувалося з ще більшими ускладненнями. Так у щурят групи ВБ24 навколо рани спостерігаеться велика кількість гною, відмічаються більш широкі ділянки флегмозного запалення з гістолізом. У щурят групи ВБ48 наявна грануляційна тканина в стінці порожнини механічної рани. Невеликим запаленням та великими некротичними змінами характеризуеться механічна рана щурят групи ВМБ24. На місці нанесення рани у нащадків-самиць групи ВМБ48 спостерігається дуже велика ділянка з гнійним інфільтратом [12].

Динаміка, що виявлена при зміні ширини пучкової зони надниркових залоз, рівня кортикостерону, протікання ранового процесу, свідчить про адекватну відповідь організму у щурят контрольних груп на больовий стрес. Аналогічні зміни спостерігали при травмах, опіках, хірургічних втручаннях, інфекціях $[1,16]$. Таким чином, зміни морфофункціонального стану надниркових залоз щурят-самиць контрольних груп спрямовані на мобілізацію захисних властивостей організму в умовах больового стресу.

Результати даного дослідження демонструють, що тривала тютюнова інтоксикація батьків-щурів призвела до морфологічних змін у структурі надниркових залоз та до порушення балансу кортикостерону у плазмі крові, як в значно більший бік у групах ПМБ24, ПМБ48, так і в значно менший у групах ПБ24, ПБ48.

Наслідки тривалого пасивного тютюнопаління батьків-щурів, в тому числі, і під час вагітності самиць-матерів, проявилися у нащадків самиць-щурят зниженням репаративних можливостей тканин, котрі входять до складу шкіри та порушуються при нанесенні механічної рани, про що свідчить порушення у них виразності ознак запалення та гальмування репарації ранового процесу. 


\section{ВИСНОВКИ}

1. При больовому стресі (механічна рана) у нащадків-самиць щурів контрольних груп установлена динаміка змін концентрації кортикостерону, що супроводжуеться нормальним перебігом фази запалення ранового процесу та його репарації.

2. Виявлено, що, як і значно збільшений рівень кортикостерону, так і зменшений рівень кортикостерону у плазмі крові щурят, батьки яких підлягали впливу тривалого пасивного тютюнопаління, призводить до порушення перебігу та виразності ознак запалення під час ранового процесу.

Останне, безумовно, е наслідком інтоксикації організму батьків продуктами тютюнопаління, внаслідок чого спостерігаеться зниження імунозахисних можливостей організму та затримка у загоенні рани.

\section{ЛITEPATУPA \\ (REFERENCES)}

1. Tjazhka OV, Vanhanova TO. Medycyna transportu Ukrai'ny 2012; 1: 93-96.

2. Gubina-Vakulik GI, Gorbach TV, Junusov Vju, et al. Sovremennaja pediatrija 2016; 6: 56-59.

3. Davydova JuV, Luk'janova IS, Lymans'ka Aju, et al. Ukr zhurn Perynatologija i Pediatrija 2020; 1(81): 45-53.

4. Kozhokar' SV, Mjetrjegunje NG, Bikir-Thorjak LI. Souremennaja pediatrija 2019: 24-32.

5. Sokolova SS, Jakovcova II, Sergijenko Lju, et al. Probl endokr patologii' 2015; 1: 113-119.

6. Tovazhnjans'ka VD, Sorokina IV, Jakovcova II. Aktual'ni problemy suchasnoi' medycyny: Visnyk ukrai'ns'koi' medychnoi' stomatologichnoi' akademii' 2015; 15(3): 259-263.

7. Küpper-Nybelen E, Lamerz A, Hebebrand J, et al. Obesity 2011; 19(12): 2411-2417.

8. Luzin VI, Belik IA, Alieva AA. Ukr morfol al'manah 2016; 14(3-4): 5-10.

9. Skotarenko TA. Vplyv kriokonservovanoi' placenty na morfofunkcional'nyj stan nadnyrkovyh zaloz v normi ta pry eksperymental'nomu perytoniti, Kyev, 2018: 23 p.

10. Pro zahyst tvaryn vid zhorstokogo povodzhennja: Zakon Ukrai'ny vid 21.02.2006, № 3447-IV, available at: http://zakon.rada.gov.ua/laws/show/3447-15.
11. Garbuzova SN. Limbiko-neokortikal'nye mehanizmy formirovanija zavisimosti ot kurenija (jeksperimental'noe issledovanie), Har'kov, 1986: 17 p.

12. Tkachenko VM, Komisova TJe. Biologija ta valeologija 2016; 18: 92-97.

13. Nikitina NS, Stepanova LI, Vereshhaka VV, et al. Visnyk problem biologii' $i$ medycyny 2019; 2(1): 168-173.

14. Rosa DF, Sarandy MM, Novaes RD, et al. Mediators Inflamm 2018: 1-12.

15. Song MY, Li X, Liu SS, et al. Zhonghua Shao Shang Za Zhi 2020; 36(10): 953-958.

16. Polykarpova AV. Visn Hark nac un-tu im. V. N. Karazina. Serija: Biologija 2011; 947(13): 19-22.

17. Tkachenko VM, Komisova TJe, Gubina-Vakulik GI. Ukr morfol al'manah 2010; 8(2): 215-216.

18. Tkachenko VM, Komisova TE. Ukr zhurn medycyny, biologii' ta sportu 2019; 5(21): 345-352.

19. Pentkowski NS, Painter MR, Thiel KJ, et al. Pharmacol Biochem Behav 2011; 100(1): 1-7.

20. Koval'chuk OI, Cherkasov VG, Dzeval's'ka IV, et al. Ukr nauk-med molodizhnyj zhurn 2015; 1(86): 10-16.

\section{НАСЛІДКИ ВПЛИВУ \\ ТРИВАЛОГО ПАСИВНОГО БАТЬКІВСЬКОГО ТЮТЮНОПАЛІННЯ НА СТАН РАНОВОГО ПРОЦЕСУ, НАДНИРКОВІ ЗАЛОЗИ ТА РІВЕНЬ КОРТИКОСТЕРОНУ У НАЩАДКІВ-САМИЦЬ ЩУРІВ}

Ткаченко В. М. ${ }^{1}$, Комісова Т. С. ${ }^{2}$, Галій А. I. ${ }^{2}$

${ }^{1}$ Харківська спеціалізована школа I-III ступенів № 134, м. Харків, Україна;

${ }^{2}$ Харківський національний педагогічний університет ім. Г. С. Сковороди, м. Харків, Україна annetka1999@ukr.net

Пристосування організму до змін різноманітних чинників довкілля обумовлено системою стресових реакцій, яка визначае індивідуальну реактивність організму та його адаптивні можливості. Проте дисбаланс нейроендокринної системи, викликаний внаслідок дії негативних чинників на ранніх етапах онтогенетичного розвитку організму, може призводити до різноманітних фоннкціональних 
розладів. Одним із розповсюджених у сучасному житті чинників, який негативно впливає на реактивність нащадків, е батьківське паління. З’ясування впливу батьківського паління під час вагітності на реактивність нащадків у ранній постнатальний період є на сьогодні актуальним питанням. Метою дослідження було дослідити вміст кортикостерону та стан ранового процесу у нащадків-самиць першого покоління на тлі пасивного батьківського тютюнопаління.

Під час проведеного дослідження виявлено, що у відповідь на больове стресове подразнення (механічна рана) рівень кортикостерону у плазмі крові нащадків-щурят на тлі батьківського пасивного паління мав різноспрямований характер і визначався тим, хто з «батьків»-щурів обкурювався та вмістом нікотину та смол у цигарках.

У нащадків-щурят груп, де самець і самиця обкурювалися цигарками з фрільтром (ПМБ24, ПМБ48), рівень кортикостерону статистично значуще збільшувався на $19 \%(\leq 0,05)$ та $18 \%(\leq 0,05)$, відповідно, порівняно з групами К 24, К 48. У нащадків-щурят груп, де обкурювався цигарками з фільтром тільки самець (ПБ24, ПБ48) та обкурювалися цигарками без фрільтру самець і самиця, рівень кортикостерону був статистично значуще нижчим контрольних показників на $16 \%(\leq 0,05)$ та $18 \%(\leq 0,05)$ порівняно з групами К24 і К48. Зниження кортикостерону відмічали і у групах ВМБ24, ВМБ48 на $9 \%$ $(\leq 0,05)$ та $15 \%(\leq 0,05)$, відповідно

Такі порушення балансу кортикостерону у нащадків-самиць, ймовірно, пов’язані з впливом на батьків-щурів (самців та самиць) компонентів тютюнового диму на момент запліднення та ембріогенезу. Наслідки тривалого впливу батьківського пасивного тютюнопаління у щурят-самиць проявилися порушенням фрази запалення механічної рани в постнатальний період, що свідчить про зниження їх реактивності на дію компонентів тютюнового диму.

К л юч ов і с лов а : надниркові залози, кортикостерон, механічна рана, пасивне паління.

\title{
EFFECTS OF LONG-TERM PASSIVE PARENTAL SMOKING ON THE CONDITION OF THE WOUND PROCESS, ADRENAL GLANDS AND CORTICOSTERONE LEVELS IN THE OFFSPRING OF FEMALE RATS
}

\author{
Tkachenko V. M. ${ }^{1}$, Komisova T. E. ${ }^{2}$, Halii A. I. ${ }^{2}$
}

${ }^{1}$ Kharkiv Specialized School of I-III grades № 134, Kharkiv, Ukraine;

${ }^{2}$ Kharkiv National Pedagogical University named after G. S. Skovoroda, Kharkiv, Ukraine

annetka1999@ukr.net

The adaptation of the organism to changes in various environmental factors is due to the system of stress reactions, which determines the individual reactivity of the organism and its adaptive capabilities. However, the imbalance of the neuroendocrine system caused by the action of negative factors in the early stages of ontogenetic development of the organism can lead to various functional disorders. One of the widespread factors in modern life, which negatively affects the reactivity of offspring, is parental smoking. Researching the parental smoking effects during pregnancy on the stress reactivity of offspring in the early postnatal period is the current issue today.

The aim of the study was to investigate the content of corticosterone and the state of the wound process in the offspring of first-generation females on the background of passive parental smoking.

During the research, it was found that in response to painful stress irritation (mechanical wound), the level of corticosterone in the blood plasma of the rat offspring to the background of parental passive smoke was multidirectional and determined which of the "parent" rats smoked and nicotine and tar content in cigarettes.

In the rat offspring groups, where both male and female were smoked cigarettes with a filter (PMB24, PMB48), the level of corticosterone increased statistically significantly by $19 \%(\leq 0.05)$ and $18 \%(\leq 0.05)$, respectively, compared with the groups K24, K48. In the rat offspring groups where only male was smoked cigarettes with a filter (PB24, PB48) and male and female were smoked cigarettes without a filter, the level of corticosterone was statistically significantly lower than the control values by $16 \%(\leq 0.05)$ and $18 \%(\leq 0.05)$ compared with groups K24 and K48. The decreases in corticosterone was also observed in the groups VMB24, VMB 48 by $9 \%(\leq 0.05)$ and $15 \%(\leq 0.05)$, accordingly.

Such corticosterone imbalances in female offspring are likely related to the effects of tobacco smoke components on rat parents (male and female) at the time of fertilization and embryogenesis. The consequences of the rats prenatal stress were displayed by a violation of the inflammatory phase of the mechanical wound in the postnatal period, which indicates a decrease in their reactivity to the stress stimulus action.

Key words: adrenal glands, corticosterone, mechanical wound, passive smoking. 